
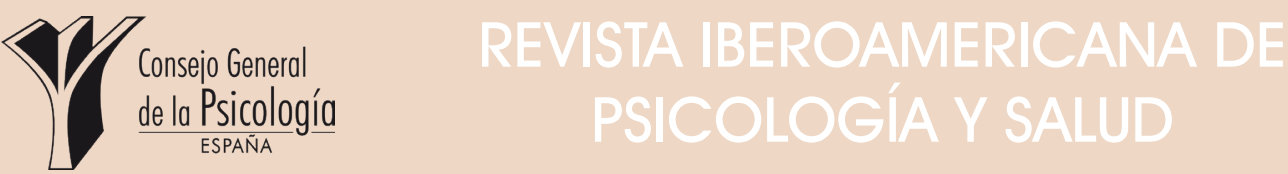

Revista Oficial de la Federación Iberoamericana de Asociaciones de Psicología (FIAP)

[Official Journal of the Latin-American Federation of Psychological Associations]

\title{
Psychopathy as a Predictor Variable of The Disposition to Steal
}

\section{Cirilo H. García', Adrián Valle², Leopoldo Daniel', Norma Grimaldo', Brenda Grimaldo' y Chriztian Calderón'}

'Universidad Autónoma de Nuevo León y ${ }^{2}$ Instituto Tecnológico y de Estudios Superiores de Monterrey

- Received: 11 - 08 - 2018 - Aceppted: 28 - 05 - 2018 . Avaliable online: 04 - 06 - 2018

ABSTRACT: The aim of this study was to compare the capacity of psychopathy and some socio-demographic variables in the prediction of the disposition to steal. The sample was composed of 100 prisoners ( 86 men and 14 women; $M=30.21$ years, SD = 8.42) and 100 participants from general community ( 86 men and 14 women; $M=26.86$ years, $S D=7.31$ ). Psychopathy and disposition to steal were assessed through self-report scales and several multiple-regression techniques were performed. Results show that socio-demographic variables are significant predictors of the disposition to steal only in the group of prison population (effect size was small, $R^{2}=3.20 \%$ ). The psychopathy is a significant predictor of the disposition to steal among prison population (large effect size: $R^{2}=72.80 \%$ ) as well as among participants from the general community (large effect size: $R^{2}=67.90 \%$ ). The interpersonal dimension of psychopathy has a greater predictive value $\left(R^{2}=75.30 \%\right)$ than the affective dimension $\left(R^{2}=23 \%\right)$ among prisoners; nevertheless, the predictive values of the affective dimension $\left(R^{2}=51.20 \%\right)$ and the interpersonal dimension $\left(R^{2}=63.40 \%\right)$ are similar among participants from the general community. The implications of these findings for diagnosis, intervention and future research are discussed.

KEYWORDS: Psychopathy, Steal Disposition, Prison Population, General Community.

\section{La Psicopatía como Variable Predictora de la Disposición a Robar}

RESUMEN: El propósito del estudio fue comparar la capacidad predictiva de la psicopatía y algunas variables sociodemográficas, sobre la disposición a robar. La muestra estaba compuesta por 100 prisioneros ( 86 hombres y 14 mujeres; $M=30.21$ años, DE = 8.42) y 100 participantes de población general (86 hombres y 14 mujeres; $M=26.86$ años, $D E=7.31$ ). La psicopatía y la disposición a robar se midieron con autoreportes, y se usaron varios análisis de regresión múltiple. Los resultados muestran que sólo en los presos las variables sociodemográficas tienen valor predictivo $\left(R^{2}=3.20 \%\right.$, tamaño del efecto pequeño). La psicopatía predice significativamente la disposición a robar, con un tamaño del efecto grande, tanto en la comunidad $\left(R^{2}=67.90 \%\right)$ como en los presos $\left(R^{2}=72.80 \%\right)$. El componente interpersonal $\left(R^{2}=75.30 \%\right)$ predice mucho mejor que el afectivo $\left(R^{2}=23 \%\right)$ en presos, pero el afectivo $\left(R^{2}=51.20 \%\right)$ predice casi tan bien como el interpersonal $\left(R^{2}=63.40 \%\right)$ en la población general. Se discuten las implicaciones de los hallazgos para la investigación, el diagnóstico y la intervención.

PALABRAS CLAVE: Psicopatía, Disposición a Robar, Población Reclusa, Población General.

What is the meaning of the verb to steal? It can be said that it means taking away the possessions of another person's, without having the authorization to do so and without having the intention to return them to the legitimate owner. This definition is based on the concept of legitimate private property and the set of rights

*Correspondence: Cirilo H. García.

Universidad Autónoma de Nuevo León.

Postal Code: 64460, Universidad Autónoma de Nuevo León, Monterrey, México.

E-mail: ciriloenator@gmail.com

(C) 2018 Sociedad Universitaria de Investigación en Psicología y Salud. Publicado por Consejo General de Colegios Oficiales de Psicólogos, España. Este es un artículo Open Access
bajo la CC BY-NC-ND licencia (http://creativecommons.org/licencias/by-nc-nd/4.0/). that it implies (North, 1990; Schlager \& Ostrom, 1993). According to the definition proposed by Hook (1993), "property may be defined as a bundle of rights held by a person over an object" (p.137). Regarding this concept, Snare (1972) had pointed out some fundamental rules as a background to better understand this concept: 1) The owner has the right to possess and use the object; 2) The owner may restrict the privilege to use the object by another person (others may use the object if, and only if, the owner consents); and 3) The owner may transfer his (her) own rights over the object to another person. 
The most important theories about the origins of the concept of private property were formulated by Boserup (1965) and Demsetz (1967), and following Acheson (2015) both theories state that "private property stems from scarce resources that are worth defending" (p.29). There is no theft without having initially accepted as legitimate the possession of something by someone. Therefore, probably in the historical social development of mankind, one might think that private property was first legalized and then initiated the possibility of stealing. When property was owned by everyone, in a kind of collective ownership (Sheldon, 1893), no one spoke of theft because nobody felt deprived of something that was inconceivable as their own in individual terms.

Likewise, with the establishment of private property, trade would have logically commenced as a legal means to be able to buy and sell goods and merchandise at a given cost in a socially accepted manner. What was socially accepted was the profit margin involved in any given transaction for it would be considered unfair to gain exorbitant profits under certain circumstances. It is, under these last circumstances, when the State (government) should enter into action in order to regulate such commercial relations. However, the surplus earned in the transaction, regardless of whether or not it is exaggerated, is not considered as theft. Then, the person consents the offeror obtain a profit margin. Therefore, we could conclude that there is only a theft if someone is involuntarily stripped of something and there is a negative absolute balance against the legitimate owner (the owner lost its property); on the other hand, it would be a commercial transaction if a person receives a product or service and, simultaneously, pays an economic cost to the offeror. After all, this conceptual issue is very controvertible and there is no agreement about it (Balkin, 2011 ; Barnett, 2005).

It is here when it is necessary to elaborate about the severe psychopathological disorder known as psychopathy, a concept to which we will refer in the following lines, adopting the definition proposed by Salvador, Arce, Rodriguez-Diaz, and Seijo (2017): "...the term psychopathy implies an early beginning of a deviant behavioral pattern in relation to what is considered a socially acceptable behavior; this pattern is stable, repetitive, and leads to individual's social disfunction" (p. 37).
Human interaction occurs in all social contexts, be it formal or informal, for example, family, school, marriage, parties, business or any other social organization. In order for this interaction to happen in a fluid manner, without major or serious setbacks that radically interrupt it, there must be mutual trust between the participants, and this is guaranteed (or, at least, the likelihood of this happening is increased) thanks to the existence of norms, rules, and laws that have been written and accepted by the persons involved in the interaction (Posner, 1997). In addition, there exist implicit moral and religious norms that encourage participants to fulfill their roles and accomplish their tasks in the anticipated way, within an atmosphere of acceptance and predictability. This scenario of successful adaptation to the human social and cultural world is due to effective breeding practices and psycho-socialization processes in which we have grown (Argyle, 2007). Nevertheless, the system may fail with some persons, mainly men. In other words, this tendency to enter into relationships with others with the desire to deceive, to thwart, to defraud, to do physical or psychological harm, using instrumental violence to obtain benefits, is more likely to happen among men (Hare, 1970).

There are some people who go through life affecting and disrupting the lives of other persons, without any signal of remorse or empathy, doing evil, damaging and deceiving their victims. This type of behavior represents the individuals themselves because it is usual for these people to act in that way on a daily basis during their multiple social interactions, that is, they are accustomed to taking advantage of others; excluded from this group of persons are those ones who occasionally keep something that is not their own or that lie very unusually, etc. This kind of antisocial behavior is known as psychopathy and usually occurs among individuals but in varying degrees. Psychopathy is a part of a serious personality disorder that greatly complicates the life and disrupts the harmonious social relationship that is sought in order to achieve happiness and productivity; indeed, people who tend to express this behavior may be considered as a kind of human predators (Kiehl \& Hoffman, 2011).

Psychopathy is basically composed of four factors or main dimensions: 1) A specific personality trait, that is, a way of being; 2) A typical mode of social interaction, which was described 
and exemplified in the previous paragraphs; 3) A special lifestyle; and 4) A long tine history of breaking the rules of civilized social coexistence, even reaching the commission of crimes that merit jail, such as robbery, violence with firearms or puncture instruments, homicide, economic fraud, rape, etc. (Hare, 2003; Harpur, Hare, \& Hakstian, 1989).

The primary aim of this study was to compare the predictive capacity of psychopathy (and two of its main dimensions, the interpersonal factor and the affective factor) and some socio-demographic variables in the prediction of the disposition to steal among prisoners and among persons recruited from the general community.

Theft has attracted the attention of psychiatry and psychology theorists and researchers for a long time and have approached this phenomenon from very different theoretical perspectives. For instance, Levy (1934), Menaker (1939), Tiebout (1930) and Tiebout and Kirkpatrick (1939) approached theft from a psychoanalytic standpoint while Henderson (1981), Luiselli and Pine (1999), Stumphauzer (1976) and Wetzel (1966) used behavioral techniques in an attempt to find ways to reduce it in specific cases, achieving encouraging results. Much research has also been done and several models have been developed on theft and, in general, on antiproductive work behavior, taking into account different personality characteristics (Berry, Ones, \& Sackett, 2007; Mount, llies, \& Johnson, 2006; Mustaine \& Tewksbury, 2002; Spector, 2011; Spector \& Fox, 2005); to date, few studies have investigated the predictive power of the affective dimension (e.g., shallow affect, callousness, and lack of empathy/remorse) and the interpersonal dimension (e.g., grandiosity, lying) of psychopathy on future criminal behavior and, in particular, on theft (Kahn, Byrd, \& Pardini, 2013; Walters, Knight, Grann, \& Dahle, 2008).

A large multicultural general community sample of young adults $(M=25.76$ years old, $S D=.95)$ participated in a research conducted by Kahn, Byrd and Pardini (2013); they find that shallow affect, callousness, and lack of empathy/ remorse, in addition to predicting various types of criminal behavior, also predict future theft, but only in Anglo-Saxons and not in African Americans. Nonetheless, several studies found that the interpersonal dimension of psychopathy had a better predictive utility for future criminal behavior than the affective dimension (Colins, Noom, \& Vanderplasschen, 2012; Theobald et al., 2016; Vahl et al., 2014), and even in other studies, those dimensions did not add any predictive value to that of past personal criminal records (Colins, Andershed, \& Pardini, 2015). Therefore, this study was performed in order to clarify to some extent these inconsistencies and contradictions in the evidence of the relationship between the components of psychopathy and the disposition to steal.

One of the hypotheses of this study was that the interpersonal dimension of psychopathy would better predict the disposition to steal than the affective dimension. A second hypothesis was that psychopathy would better predict the disposition to steal than age, schooling, and self-perceived socioeconomic status. A third hypothesis was that psychopathy would better predict the disposition to steal in the group of people accused of committing various crimes, including theft or robbery, than in the general community.

The problem addressed in this study refers to the relationship between psychopathological personality variables, such as psychopathy and disposition to steal. Specifically, the research question that was intended to answer was: how much can the variable disposition to steal be predicted taking into account the interpersonal and the affective dimensions of psychopathy in comparison to a set of socio-demographic variables (such as age, schooling, and socioeconomic status) in a group of prisoners and in a sample of persons from the general community?

\section{METHOD}

\section{- PARTICIPANTS}

Two hundred participants were recruited for this study. That sample was composed of two subsamples:

1) One hundred volunteers from general community. The sample was composed of 86 men and 14 women. The main age of these participants was 26.86 years $(S D=7.31$; range: 19 to 59 years). Average years in school was 10.50 (SD = 2.99; range: $0-19$ years) and the mean self-perceived socioeconomic status was middle - low, $(M=4.46$; $S D=1.31$; range: 0 
to 19). This subsample was composed of 86 men and 14 women.

2) One hundred prisoners inhabiting a state installation of medium security level and who have been incarcerated while expecting sentence from the tribunal. The sample was composed of 86 men and 14 women. The mean age of these participants was 30.21 years $(S D=8.42$; range: 19 to 60 years). Average years in school was 8.32 $(S D=2.42$; range: 0 to 24 years $)$, and the mean self-perceived socioeconomic status was low high $(M=2.79$; $S D=1.26$; range: 1 to 6$)$. The mean time of imprisonment was 17.34 weeks (SD $=11.20$; range 1 to 52 weeks)

\section{-INSTRUMENTS}

The affective and interpersonal dimensions of psychopathy were assessed through a selfreport instrument composed of thirteen Liker-type items with high internal consistency $(\alpha=.92)$ : five to measure lack of empathy (affective dimension), three items to measure grandiosity, and five items to measure the capacity and/or facility to lie to others. The interpersonal dimension is constituted precisely by these last two components. This shortform, Likert-type scale was derived by Garcia et al. (2012) from another scale composed of 36 items, showing goodness of fit and evidence of validity through confirmatory factor analysis (Garcia et al., 2012). In addition, the assessment of the disposition to steal was performed in this study by an instrument introduced for the first time in this study and which is composed of 27 items. Finally, a simple socio-demographic questionnaire designed to obtain information regarding age, sex, years of schooling, and selfperceived socioeconomic status (low-low, lowmedium, low-high, middle-low, middle-middle, middle-high, high-low, high-middle and highhigh).

\section{•STUDY DESIGN}

A quasi-experimental, cross-sectional and survey design has been implemented.

\section{- DATA ANALYSIS}

Statistical calculations were executed through SPSS 21 and AMOS 21. Likewise, the R-Module was used to perform exploratory factor analysis and Horn's Parallel Analysis. Also, the Student t, Kolmogorov-Smirnov Z statistical tests, multiple regression analysis and the formulae to estimate effect size were used (Cohen, 1988; Hyde, 2005). To obtain the measuring model of the disposition to steal scale the estimation method of confirmatory factor analysis unweighted least squares was used.

\section{-PROCEDURE}

An undergraduate student from the School of Psychology at Universidad Autónoma de Nuevo León, located in Monterrey, Mexico, and who had enough experience in administration of selfreported instruments, was responsible for data collection. The questionnaires were administered to 100 prisoners of a medium security prison in the state of Nuevo León, known as Center for Prevention and Social Readjustment (CERESO in Spanish) Topo Chico and to 100 residents of the metropolitan area of Monterrey, Nuevo Leon.

In the case of the sub-sample composed of prisoners, the letter of institutional authorization to recruit the subsample of prisoners was obtained. The information was collected at the visitors' room of CERESO, with the collaboration of a federal criminal lawyer. The lawyer asked the prisoners for informed consent to participate in the study, answered their questions and assured them that the information collected would be used for research purposes only and would not affect, in any way, the legal process they were going through. After this step, the interviewer (the psychology student) administered the questionnaire to the participants, gave instructions to complete it and answered any questions regarding the questionnaire. Through several sessions the questionnaires were applied to 20 to 30 participants each time; each participant answered the whole questionnaire in a single session, and the time required to administer/ complete the questionnaire never exceeded to 15 minutes. The number of questionnaires applied in each session was variable because, at each visit, and for different reasons, not all prisoners were available, for instance, sometimes some prisoners were held in an isolation area. The variation in the number of questionnaires applied per week ranged from five to 20, and this subsample of 100 cases was fully collected and interviewed in approximately three months. 
On the other hand, after providing informed consent, participants from general community answered the questionnaires at their homes, workplaces, or public spaces.

\section{RESULTS}

The measures of central tendency and dispersion are shown in Tables 1 and 2. Table 1 shows mean, median, standard deviation, internal consistency (Cronbach's coefficient alpha and McDonald's coefficient omega) as well as the values for GFI (Goodness of Fit) and RMSR (Root Mean Square Residual) for the 21 -item scale that assesses the disposition to steal; after performing exploratory factor analysis. The statistical test Kolmogorov-Smirnov Z used to evaluate normality was non-significant $(p>$.05).

\section{-EXPLORATORY FACTOR ANALYSIS}

Exploratory factor analysis of the Scale of Disposition to Steal was carried out. The correlation matrix of the 21 items of the scale showed adequate properties for factor extraction. Its determinant tended to $0(|R|<.01)$, the KaiserMeyer-Olkin (KMO) test for sampling adequacy was higher than $.60(\mathrm{KMO}=0.905)$, and the null hypothesis of equivalence of the correlation matrix to an identity matrix by Bartlett's sphericity test was rejected $\left(\chi^{2}=2782.35, d f=210, N=\right.$ $200, p<.001)$. Likewise, Horn's parallel analysis was performed because, according to Courtney (2013), it is one of the methods with highest precision to define the number of factors to retain.

Factor extraction was performed through unweighted least squares estimation method

\section{Table 1}

Descriptive statistics, internal consistency (coefficients $\alpha$ and $\varpi$ ), GFI and RMSR.

\begin{tabular}{|c|c|c|c|c|c|c|c|}
\hline Scale & Mean & Median & SD & Alpha $\alpha$ & Omega $\varpi$ & GFI & RMSR \\
\hline $\begin{array}{c}\text { Disposition to } \\
\text { steal }\end{array}$ & 47.89 & 47 & 12.70 & .93 & .82 & .90 & .06 \\
F1 & 27.06 & 26 & 7.82 & .90 & .83 & .91 & .06 \\
F2 & 20.84 & 21 & 5.87 & .86 & .79 & .93 & .06 \\
\hline
\end{tabular}

Table 2

Descriptive statistics in general community and prison population sub-samples.

\begin{tabular}{|l|c|c|c|}
\hline \multicolumn{1}{|c|}{ Scale } & Mean & Median \\
\hline General Population & \multicolumn{2}{|c|}{ SD } \\
\hline Disposition to Steal & 41.35 & 22 & 9.82 \\
\hline F1 & 23.52 & 16.5 & 5.55 \\
\hline F2 & 17.83 & & 5.01 \\
\hline Prisoners & \multicolumn{3}{|c|}{} \\
\hline Disposition to Steal & 54.43 & 56.5 & 11.88 \\
\hline F1 & 30.59 & 32 & 7.40 \\
\hline F2 & 23.84 & 24.5 & 5.07 \\
\hline
\end{tabular}


Table 3

Factor structure of the 21 -item scale for assessing the disposition to steal.

\begin{tabular}{|c|c|c|}
\hline \multirow{2}{*}{ Item } & \multicolumn{2}{|c|}{ Factors } \\
\hline & $\mathrm{F} 1$ & $\mathrm{~F} 2$ \\
\hline R36. Private property harms the poor. & .81 & \\
\hline R31. No one sins if he/she steals because of hunger. & .78 & \\
\hline R19. If I can, I'Il keep things that are not my own. & .76 & \\
\hline R14. If I can, I'll keep somebody else's money. & .66 & \\
\hline R5. It's correct to keep whatever other person has forgotten. & .60 & \\
\hline R27. Sometimes it is unfair to respect others' properties. & .59 & \\
\hline R25. The person in charge of sharing out always keeps the biggest bit for himself. & .54 & \\
\hline R16. If I can, I will never pay what I owe. & .53 & \\
\hline $\begin{array}{l}\text { R7. The real thieves are those entrepreneurs who pay the workers little for their } \\
\text { work. }\end{array}$ & .49 & \\
\hline R11. It is a sin to allow some to have little and others to possess very much. & .49 & \\
\hline $\begin{array}{l}\text { R3. If my family or myself are lacking something that others have in excess, it is } \\
\text { fair to appropriate what we need. }\end{array}$ & .43 & \\
\hline R26. Sometimes it is convenient to keep something that is not our own. & .41 & \\
\hline $\begin{array}{l}\text { R33. It is false the statement that claims that respect for the rights of others is } \\
\text { peace. }\end{array}$ & & .71 \\
\hline R23. A thief that steals from another thief has 100 years or forgiveness. & & .66 \\
\hline R34. The law protects only the rich people. & & .65 \\
\hline R39. God forgives the poor when he/she steals. & & .65 \\
\hline R32. Stealing because of hunger is morally justified. & & .60 \\
\hline R40. In the name of the rights of others the poor ones are exploited. & & .55 \\
\hline R29. When you are hungry, it is justified to steal. & & .50 \\
\hline $\begin{array}{l}\text { R21. If I'm going to make more money, I'm able to keep something that is nor } \\
\text { my own. }\end{array}$ & & .46 \\
\hline R28. Only for rich people it is convenient the respect for private property. & & .45 \\
\hline
\end{tabular}


followed by an Oblimin rotation. Both the unweighted least squares estimation method and Horn's parallel analysis showed a two-factor structure for the scale of disposition to steal, which accounted for $43.10 \%$ of the total variance. The first factor was composed of twelve items and the second factor was composed of nine items. Table 3 shows the factor structure of this scale.

Horn's parallel analysis was performed using Courtney's recommendations (2013). The analysis clearly identified two eigenvalues (8.67 and 1.52), which were above the point of intersection and explained $48.60 \%$ of the variance. With this result, the two-factor structure of the scale of disposition to steal was ratified. It is important to mention that Pearson's productmoment correlation matrix ( $r$ ) was used for all the previously described analyzes.

\section{- CONFIRMATORY FACTOR ANALYSIS}

Although two factors were obtained through exploratory factor analysis, it was decided to test the unidimensionality of the construct through confirmatory factor analysis because the correlation between these two factors was very high $(r=.82)$. This allowed the authors to obtain results that provided guidance in the analysis of the predictive utility of psychopathy on the disposition to steal, assuming that this last construct is unidimensional too. The measuring model for the original 27-item scale to assess the disposition to steal was performed through unweighted least squares estimation method because, after performing the non-parametric KolmogorovSmirnov test, the distribution of scores did not fit to a normal curve $\left(Z_{K-S}=1.84, p=.02\right)$. After eliminating ten items because of having squared multiple correlation $\left(R^{2}\right)$ coefficients below .30, a final solution composed of 17 items showed goodness of fit.

The items removed were: 1) The real thieves are those entrepreneurs who pay the workers little for their work $\left.\left(R^{2}=26 \%\right), 2\right)$ It is a sin to allow some to have little and others to possess very much $\left.\left(R^{2}=21 \%\right), 3\right)$ I am not asking to be given money; what I ask is to be put where I can make it $\left.\left(R^{2}=11 \%\right), 4\right)$ A thief that steals from another thief has 100 years or forgiveness $\left(R^{2}\right.$ $=27 \%)$, 6) It is false the statement that claims that respect for the rights of others is peace $\left(R^{2}=\right.$ $27 \%), 7)$ Stealing is a $\left.\sin \left(R^{2}=12 \%\right), 8\right)$ No one has the right to accumulate superfluous goods while someone is lacking what is necessary $\left(R^{2}\right.$ $=10 \%)$, 9) God forgives the poor when he/she steals $\left(R^{2}=26 \%\right)$ and 10) In the name of the rights of others the poor ones are exploited $\left(R^{2}\right.$ $=24 \%$ ).

The goodness of fit of the model for the construct disposition to steal was very good: $X^{2} / d f=.96 ; R M R=.05 ; G F I=.98 ; A G F I=$ .98; NFI $=.98$. The items that were retained had squared multiple correlation $\left(R^{2}\right)$ coefficients greater than .30. These items were: 1) Often doing justice involves keeping what is not of our own $\left.\left(R^{2}=43 \%\right), 2\right)$ If my family or myself are lacking something that others have in excess, it is fair to appropriate what we need $\left(R^{2}=51 \%\right)$, 3) It's correct to keep whatever other person has forgotten $\left(R^{2}=62 \%\right)$, 4) We must take away something to others who have properties in excess $\left.\left(R^{2}=34 \%\right), 5\right)$ It is correct to take away something of what others own in excess $\left(R^{2}=\right.$ $49 \%), 7)$ If I can, I will never pay what I owe $\left(R^{2}\right.$ $=37 \%)$, 8) If I can, I'll keep things that are not my own $\left(R^{2}=48 \%\right)$, 9) If I'm going to make more money, I am able to keep something that is nor my own $\left.\left(R^{2}=34 \%\right), 10\right)$ The person in charge of sharing out always keeps the biggest bit for himself $\left.\left(R^{2}=54 \%\right), 11\right)$ Sometimes it is convenient to keep something that is not our own $\left(R^{2}=30 \%\right)$, 13) When you are hungry, it is justified to steal $\left(R^{2}\right.$ $=39 \%)$, 14) No one sins if he/she steals because of hunger $\left.\left(R^{2}=47 \%\right), 15\right)$ Stealing because of hunger is morally justified $\left.\left(R^{2}=37 \%\right), 16\right)$ The law protects only the rich people $\left(R^{2}=35 \%\right)$ and 17) Private property harms the poor $\left(R^{2}=45 \%\right)$. The internal consistency of the scale, assessed in the whole sample $(N=200)$ through Cronbach's alpha coefficient was high $(\alpha=.93)$. Cronbach's alpha coefficient was also high in the subsample $(N=100)$ of prisoners $(\alpha=.93,95 \% / C=.91$ $.95)$ but was somewhat lower in the subsample of participants from general community $(\alpha=.87$, $95 \% I C=.83$ to .90$)$.

The internal consistency of the 13-item psychopathy scale, assessed in the whole simple ( $N=200)$ through Cronbach's alpha coefficient was acceptable $(\alpha=.74)$ and in the subsample ( $N$ $=100$ ) of participants from general community $(\alpha=.74,95 \%$ IC $=.66$ to .81$)$; nevertheless, it reached a lower value in the subsample $(\mathrm{N}=$ 100) of prisoners $(\alpha=.64,95 \% / C=.52$ to .73). 


\section{-MULTIPLE LINEAL REGRESSION MODELS}

Several multiple linear regression models were tasted with each subsample: 1) A sociodemographic model, in which the predictor variables were age, years of schooling and self-perceived socioeconomic status while the predicted variable was the disposition to steal; 2) A global psychopathological model, in which the predictor variable was psychopathy and the predicted variable was the disposition to steal; 3) A partial psychopathological model one, in which the predictor variable was de interpersonal dimension of psychopathy and the predicted variable was the disposition to steal; and 4) A partial psychopathological model two, in which the predictor variable was the affective dimension of psychopathy and the predicted variable was the disposition to steal.

In the subsample of participants from the general community, the value of the corrected $R^{2}$ coefficient of the socio-demographic model was $1.60 \%$ and, according to Cohen (1988), the effect size is not even considered to be small because the value of $R^{2}$ is lower than 1.96; none of the predictor variables reached statistical significance $(\beta$ of age $=$ $.10, t=1.01, p=.32 ; \beta$ of schooling $=.07, t=$ $.70, p=.48$, and $\beta$ of socioeconomic status $=$ $.02, t=.17, p=.86$ ).

In the subsample of prisoners, the value of the corrected $R^{2}$ coefficient of the socio-demographic model was $3.20 \%$ and, according to Cohen (1988), the effect size is considered to be small because $12.99 \%>R^{2}>1.96 \%$. One predictor variable (age) reached statistical significance $(\beta=$ $-.24, t=2.36, p=.02)$; nonetheless, two predictor variables did not reach statistical significance: schooling $(\beta=.04, t=.37, p=.71)$ and selfperceive socioeconomic status $(\beta=.04, t=.37$, $p=.71)$

In the subsample of participants from the general community, the value of the corrected $R^{2}$ coefficient of the global psychopathological model was $67.90 \%$, and the predictor variable psychopathy reached statistical significance $(\beta=.83, t=14.52$, $p=.001)$; in the subsample of prisoners, the value of the corrected $R^{2}$ coefficient of this model was $72.80 \%$, and the predictor variable psychopathy also reached statistical significance $(\beta=.86,+=$ $16.31, p=.001)$. In both cases, and according to Cohen (1988), since the value of $R^{2}$ is higher than $26 \%$, the effect size is considered to be large.
Nevertheless, the affective dimension of psychopathy (partial psychopathological model two), in the subsample of prisoners, yielded a corrected $R^{2}$ coefficient of 23\% (medium effect size) that was statistically significant $(\beta=.49,+=5.53, p=.001)$, while the interpersonal dimension of psychopathy (partial psychopathological model one) yielded a corrected $R^{2}$ coefficient of $75.30 \%$ (large effect size) that was also statistically significant ( $\beta=$ $.87, t=17.40, p=.001)$. In the subsample of participants from the general community, the affective dimension of psychopathy (partial psychopathological model two) yielded a corrected $R^{2}$ coefficient of $51.20 \%$ (large effect size), that was statistically significant $(\beta=.72, t=10.24, p=.001)$ while the interpersonal dimension of psychopathy (partial psychopathological model one) yielded a corrected $R^{2}$ coefficient of $63.40 \%$ (large effect size) that was also statistically significant $(\beta=$ $.80, t=13.13, p=.001$ ).

After comparing the subsample of participants from the general community $(N=$ $100)$ and the subsample of prisoners $(N=100)$, there are statistically significant differences in the socio-demographic variables: age $(M=26.86$, $S D=7.31 ; M=30.21, S D=8.43 ; t=3, p=$ $.003 ; d=.43$ [medium effect size, according to Hyde (2005) because .65 $>d>.36]$ ), schooling $(M=10.15, S D=3 ; M=8.32, S D=2.43 ;+$ $=4.75, p=.001 ; d=.68$ [large effect size, according to Hyde (2005) because $1>d>$ $.66])$, and socioeconomic status $(M=4.46$, $S D=1.31 ; M=2.79, S D=1.27 ; \dagger=$ 9.16, $p=.001 ; d=1.29$ [very large effect size, according to Hyde (2005) because $d>$ 1 ]). Likewise, there are statistically significant differences between the two subsamples in the level of psychopathy $(M=53.04, S D=10.91$; $M=63.29, S D=9.33 ; t=7.14, p=.001 ; d$ $=1.01$ [very large effect size, according to Hyde (2005) because $d>1]$ ) and the disposition to steal $(M=47.49, S D=12.12 ; M=63.93$, $S D=14.85 ; t=8.58, p=.001 ; d=1.22$ [very large effect size, according to Hyde (2005) because $d>1])$. The levels of psychopathy and disposition to steal are higher in the subsample of prisoners than in the subsample of participants from the general community. These analyses were performed because there were not missing data. 


\section{DISCUSSION}

The results of this research support the first hypothesis regarding the disposition to steal, that is, the disposition to steal is better predicted by the interpersonal dimension of psychopathy than by the affective dimension, and this is true for both subsamples, although the affective dimension has a higher weight in the subsample from the general population than in the subsample of prison population.

These results are concordant with the findings reported by Kahn, Byrd, and Pardini (2013) and Walters et al., (2008). The two dimensions of psychopathy assessed in this research were: 1) Interpersonal dimension (A-Grandiosity, three items [1A I am surrounded by lots of dumb and stupid people, 2A Only dumb people get robbed, 3A Dumb people deserve to be deceived]; B-Lying, five items [ $1 \mathrm{~B}$ It is justified to lie to protect yourself, 2B I enjoy deceiving others, 3B I enjoy lying, 4B Lying is justified in order to get what you want, $5 \mathrm{~B}$ The best thing I can do is to tell the truth]) and 2) Affective dimension (Lack of empathy, five items): 1 - If I do harm to others is because they deserve it, 2- I manipulate other people to get what I want, 3- It is correct to make others suffer if they deserve it, 4- I feel the pain of others in my own flesh, and 5 - I reach my goals taking other people into account.

The fact that psychopathy and its interpersonal and affective dimensions are efficient to predict the disposition to steal in the subsample of participants from the general community has implications that deserve attention. It is quite possible that participants in the subsample of the general community also have, to some degree, the affective and interpersonal dimensions of psychopathy, but have not (so far) violated social norms to commit flagrantly the crime of theft and being imprisoned due to theft, or it might be the case that they have committed theft but those affected have not proceeded to sue; or it might be also possible that they have been accused but have not been sentenced, or well, no one has discovered nor accused them as the perpetrators of a theft, having prevailed the impunity.

All or some of these assumptions receive the empirical support that in both subsamples it was found a not very different percentage of participants considered to be, or diagnosed as, psychopaths if we take into account the criterion proposed by Patrick \& lacono (1989) for such a diagnosis, that is, to obtain a score in the highest third of scores of the scale (this criterion was fulfilled by $20 \%$ of the sample of prison population and $12 \%$ of participants from the general community). Nevertheless, the very large effect size that was found in the mean differences of global psychopathy and disposition to steal in both subsamples reveals the huge social importance that this diagnosis possesses, a diagnosis that characterized very well both social segments. Thus, it would be very important for decision makers to take into account this knowledge and use it someway, particularly in the administration of justice, and for using some therapeutic approaches intended to reduce this psychopathological disturbance, for example, cognitive-behavioral therapy (Arce, Fariña, \& Novo, 2014). The scale to assess psychopathy could be used as a means, weighted with other elements, for the selection of personnel in those organizations in which the employees will have access to the management of money or the accounts of clients, for instance, cashiers of bank executives.

Regarding the second hypothesis of this study which asserted that psychopathy would predict the disposition to steal better than sociodemographic variables (age, schooling and selfperceived socioeconomic status), the results show that the hypothesis is supported by the empirical evidence obtained from both subsamples. Regarding the third hypothesis, that asserted that psychopathy would better predict the disposition to steal in the group of persons accused of various crimes, including theft/robbery than in the group of participants from the general community, the findings point clearly in that direction,

A limitation of this study is that it was not recorded how many participants from the subsample of prison population accused of a crime (including theft/robbery) were, indeed, exclusively accused of theft/robbery. It would be convenient, in future studies, to include only prison population accused exclusively of theft/robbery in order to verify the replicability of the findings reported here. A second limitation was that since this study lacked information about criminal history and personality disorders (antisocial personality disorder or borderline personality disorder), it was not possible to say how many prisoners could have had a tendency or disposition to become a 
batterer or a rapist (Herrero, Torres, FernandezSuarez, \& Rodriguez-Diaz, 2016; MartinezCatena \& Redondo, 2017). Likewise, it would be convenient, in future studies, to use a research design with paired samples to compare not only prison population accused of theft/robbery but also prison population convicted for having committed that crime, as well as a matched subsample composed of persons from the general community. This last suggestion is raised because there is a certain unknown percentage of prison population accused of theft/robbery who do not reach any sentence because the commission of the crime is not credited or because they are, indeed, innocent.

A product derived from the present study was the creation of a new scale to assess the disposition to steal, which can be used mainly in Latin America for purposes of investigation, diagnosis and intervention, since it has been shown that these scales fulfilled the necessary and appropriate psychometric requirements (validity and reliability) in order to be able to recommend its use. Furthermore, each one of the two subscales (one of nine items and one of 12 items) that were found in this study can be used as equivalent short forms to assess the construct. Since the whole scale and its two subscales are self-report, Likert-type instruments, they have the advantage of efficiency regarding administration time and effectiveness due to the low cost of their use (Lilienfeld \& Fowler, 2006).

It remains to be determined, in future research, why the affective dimension of psychopathy did have an important predictive value in the disposition to steal in the subsample composed of participants from the general community $\left(R^{2}=\right.$ $51.20 \%$ ) and this did not happen in the subsample composed of the prison population ( $R^{2}=23 \%$ ). Probably, owing to the fact that the affective dimension was assessed taking into account only its component of lack of empathy, the data may be pointing out that when persons lack identification with others or when they do not care about what others think or need, then they are prone to keep, in a given moment, what is not their own; this phenomenon also occurs in the subsample of prison population, but in a lesser proportion, suggesting that the affective dimension does not play an important role in the disposition to steal among them.

Likewise, it also deserves to be noted that the predictive value of the interpersonal dimension of psychopathy is almost as high in the subsample of prisoners ( $\mathrm{R}^{2}=75.30 \%$ ) as in the subsample of participants from the general community $(R=$ 63.40\%). Perhaps, the fact of having the disposition to steal, in a given moment, or the planning of a theft/robbery, involves lying, deceiving, defrauding the trust of others, and probably also requires a degree of underestimation of the ability of the deceived ones to realize of the intentions of the scammers, or that when the deceived ones become able to realize of the intentions of the scammers, they (the scammers) will be already out of reach; apparently, these considerations might be operating both in the people of the general community prone to stealing, as well as in the group of prisoners, but to a greater degree in the latter group.

Finally, owing to the contradictory nature of the reported findings about the importance of the affective and interpersonal dimensions of psychopathy as a risk factor to predict criminal behavior, it is probably better to wait for more research to be done about this matter before taking a decision in favor or against these empirical findings (Colins, Andershed, \& Pardini, 2015).

The differences found may respond, among other things, to the fact that different self-report instruments have been used to assess those dimensions and might be, in some sense, only useful in the samples (or contexts) where they were generated; thus, they may lack sufficient external validity to achieve a more generalizable knowledge. In other words, an effort is needed in this area in order to integrate, in a single instrument of sufficient validity and reliability, the different efforts that have been done so far in different samples and contexts, even in the same region or country (Garcia-Cadena et al., 2016).

\section{- Conflict of interest}

The authors declare no conflict of interest.

\section{REFERENCES}

Acheson, J. M. (2015). Private land and common oceans. Analysis of the development of property regimes. Current Anthropology, 56(1), 28-55. Arce, R., Fariña, F., \& Novo, M. (2014). Competencia cognitiva en penados primarios y reincidentes: Implicaciones para la 
reeducación. Anales de Psicología, 30 (1), 259 266. doi:10.6018/analesps.30.1.158201

Argyle, M. (2007). Social Interaction. New York: Routledge.

Balkin, J. M. (2011). Living Originalism. Cambridge: Harvard University Press.

Barnett, R. E. (2005). Restoring the Lost Constitution. Princeton: Princeton University Press.

Berry, C. M., Ones, D. S., \& Sackett, P. R. (2007). Interpersonal deviance, organizational deviance and their common correlates: A review and meta-analysis. Journal of Applied Psychology, 92, 410-424. doi:10.1037/00219010.92.2.410

Boserup, E. (1965). The Conditions of Agricultural Growth: The Economics of Agrarian Change Under Population Pressure. Chicago: Aldine.

Cohen, J. (1988). Statistical Power Analysis for The Behavioral Sciences. Mahwah: Lawrence Erlbaum Associates.

Colins, O. F., Noom, M., \& Vanderplasschen, W. (2012). Youth psychopathic traits inventoryshort version: A further test of the internal consistency and criterion validity. Journal of Psychopathology and Behavioral Assessment, 34(4), 476-486. doi:10.1007/s10862-0129299-0

Colins, O. F., Andershed, H., \& Pardini, D. A. (2015). Psychopathic traits as predictors of future criminality, intimate partner aggression, and substance use in young adult men. Law and Human Behavior, 39(6), 547-558. doi:10.1037//hb0000148

Courtney, M. (2013). Determining the number of factors to retain in EFA: Using the SPSSR-Menu v2.0 to make more judicious estimations. Practical Assessment, Research \& Evaluation, 18(8), $1-14$.

Demsetz, H. (1967). Toward a theory of property rights. American Economic Review, 57(2), 347-359.

García, C. H., Moral, J., Frías, F., Valdivia, J. A., \& Díaz, H. L. (2012). Family and sociodemographic risk factors for psychopathy among prison inmates. The European Journal of Psychology Applied to Legal Context, 4(2), $119-134$.

García-Cadena, C. H., Téllez-López, A., RamírezAguillón, G., Ramírez-Hernández, E., \& Pérez-Cota, E. J. (2016). Toward a Global Conceptualization and Measurement in Positive
Psychology. In Bowers (Ed.), Psychological Well-Being. Cultural Influences, Measurement Strategies and Health Implications (pp. 21 -42). New York: Nova Science Publishers.

Hare, R. D. (1970). Psychopathy: Theory and Research. Hoboken: John Wiley \& Sons In

Hare, R. D. (2003). Manual for the Hare Psychopathy Checklist-Revised. Toronto: MultiHealth Systems.

Harpur, T. J., Hare, R. D., \& Hakstian, A. R. (1989). Two-factor conceptualization of psychopathy: Construct validity and assessment implications. Psychological Assessment, 1(1), 6-17. doi:10.1037/1040-3590.1.1.6

Herrero, J., Torres, A., Fernández-Suárez, A., \& Rodríguez-Díaz, F. J. (2016). Generalists versus specialists: Toward a typology of batterers in prison. The European Journal of Psychology Applied to Legal Context, 8, 19-26. doi:10.1016/i.ejpal.2015.09.002

Henderson, J. Q. (1981). A behavioral approach to stealing: A proposal for treatment based on ten cases. Journal of Behavior Therapy and Experimental Psychiatry, 12(3), 231-236. doi:10.1016/0005-7916(81)90051-3

Hook, J. (1993). Judgments about the right to property from preschool to adulthood. Law and Human Behavior, 17(1), 135-146. doi:10.1007/BF01044542

Hyde, J. S. (2005). The gender similarities hypothesis. American Psychologist, 60(6), 581 592. doi:10.1037/0003-066X.60.6.581

Kahn, R. E., Byrd, A. L., \& Pardini, D. A. (2013). Callous-unemotional traits robustly predict future criminal offending in young men. Law and Human Behavior, 37(2), 87-97. doi:10.1037/ $\underline{\text { b0000003 }}$

Kiehl, K. A., \& Hoffman, M. B. (201 1). The criminal psychopath: History, neuroscience, treatment, and economics. Jurimetrics, 51, 355-397.

Levy, E. (1934). Psychoanalytic treatment of a child with a stealing compulsion. American Journal of Orthopsychiatry, 4(1), 1-23. doi:10.1111/i.1939-0025.1934.tb06272.x

Lilienfeld, S. O., \& Fowler, K. A. (2006). The selfreport assessment of psychopathy: Problems, pitfalls, and promises. In C. Patrick (Ed.), Handbook of psychopathy (pp. 107-132). New York, NY: Guilford Press.

Luiselli, J. K., \& Pine, J. (1999). Social control of childhood stealing in a public school: A case study. Journal of Behavior Therapy and 
Experimental Psychiatry, 30(3), 231-239. doi:10.1016/50005-7916(99)00023-3

Martínez-Catena, A., \& Redondo, S. (2017). Psychological treatment and therapeutic change in incarcerated rapists. The European Journal of Psychology Applied to Legal Context, 9, 41 -49. doi:10.1016/i.eipal.2016.11.001

Menaker, E. (1939). A contribution to the study of the neurotic stealing symptom. American Journal of Orthopsychiatry, 9(2), 368-378. doi:10.1111/i.1939-0025.1939.tb05604.x

Mount, M., llies, R., \& Johnson, E., (2006). Relationship of personality traits and counterproductive work behaviors: The mediating effects of job satisfaction. Journal of Personnel Psychology, 59(3), 591-622. doi:10.1111/i.1744-6570.2006.00048.x

Mustaine, E. E., \& Tewksbury, R. (2002). Workplace theft: An analysis of student employee Venders and job attributes. American Journal of Criminal Justice, 27(1), 111-127. doi:10.1007/ BF02898973

North, D. (1990). Institutions, Institutional Change and Economic Performance. Cambridge: Cambridge University Press.

Patrick, C. J., \& lacono, W. G. (1989). Psychopathy, threat, and polygraph test accuracy, Journal of Applied Psychology, 74(2), 347-355. doi:10.1037/0021-9010.74.2.347

Posner, R. A. (1997). Social norms and the law: An economic approach. The American Economic Review, 87(2), 365-369.

Salvador, B., Arce, R., Rodriguez-Díaz, F., \& Seijo, D. (2017). Evaluación psicométrica de la psicopatía: una revisión meta analítica. Revista Latinoamericana de Psicología, 49, 36-47. doi:10.1016/i.rlp.2015.09.015

Schlager, E., \& Ostrom, E. (1993). Property rights regimes and coastal fisheries: An empirical analysis. In Anderson \& Simmons (Eds.), The Political Economy of Customs and Cultures: Informal Solutions to The Commons Problems (pp. 13-41).

Sheldon, W. L. (1893). What justifies private property? International Journal of Ethics, 4(1), 17-40. doi:10.1086/intejethi.4.1.2375709

Snare, F. (1972). The concept of property. American Philosophical Quarterly, 9(2), 200206.
Spector, P. E. (2011). The relationship of personality to counterproductive work behavior (CWB): An integration of perspectives. Human Resource Management Review, 21, 342-352. doi:10.1016/i.hrmr.2010.10.002

Spector, P.E., \& Fox, S. (2005). The stressor-emotion model of counterproductive work behavior. In Spector \& Fox (Eds.), Counterproductive Work Behavior: Investigation of Actors and Targets (pp. 151 -174). Washington, DC: APA Books. doi: $10.1037 / 10893-007$

Stumphauzer, J. S. (1976). Elimination of stealing by self-reinforcement of alternative behavior and family contracting. Journal of Behavior Therapy and Experimental Psychiatry, 7(3), 265268. doi:10.1016/0005-7916(76)9001 1-2

Theobald, D., Farrington, D. P., Coid, J. W., \& Piquero, A. R. (2016). Are male perpetrators of intimate partner violence different from convicted violent offenders? Examination of psychopathic traits and life success inmates from a community survey. Journal of Interpersonal Violence, 37(9),1687-1718. doi:10.1177/0886260515569061

Tiebout, H. M. (1930). Delinquency: Problems in the causation of stealing. American Journal of Psychiatry, 86(5), 817-826. doi:10.1176/ aip. 86.5817

Tiebout, H. M., \& Kirkpatrick, M. E. (1939). Psychiatric factors in stealing. American Journal of Orthopsychiatry, 2(2), 114-123. doi:10.1 11 1/i.1939-0025.1932.tb05170.x

Vahl, P., Colins, O. F., Lodewijkcs, H. P. B., Markus, M., Doreleiiers, T. A. H., \& Vermeiren, R. R. J. M. (2014). Psychopathic-like traits in detained adolescents: Clinical usefulness of self-report. European Child \& Adolescent Psychiatry, 23(8), 691-699. doi:10.1007/s00787-013-0497-4

Walters, G. D., Knight, R. A., Grann, M., \& Dahle, K. (2008). Incremental validity of the Psychopathy Checklist facet scores: Predicting release outcome in six samples. Journal of Abnormal Psychology, 117(2), 396-405. doi:10.1037/0021-843X.117.2.396

Wetzel, R. (1966). Use of behavioral techniques in a case of compulsive stealing. Journal of Consulting Psychology, 30(5), 367-374. doi: $10.1037 / \mathrm{h} 0023830$ 